\title{
Bibliometric analysis of psychological interventions with a randomized controlled trial in parents of children with disabilities from 1980 to 2019
}

\author{
Análisis bibliométrico de intervenciones psicológicas con ensayo controlado \\ aleatorizado en padres de niños con discapacidad de 1980 a 2019 \\ Angélica Janneire García López ${ }^{a}$, Karla Salinas Ríos ${ }^{b}$, Luz Adriana Orozco \\ Ramírez $^{c}$
}

\begin{abstract}
Children born with a specific disability require primary caregivers who are trained to care for and enhance their abilities. The present study is a bibliometric analysis of the publications of psychological interventions with a randomized controlled trial (RCT) that have been carried out in parents of children with disabilities in the period from 1980 to 2019. As part of the search strategy, we used the Cochrane Library, Pubmed and Elsevier databases, performing different combinations with the keywords "children with disabilities", "parents", "intervention" and "randomized controlled trial". The results obtained reflect that 2015 was the year with the highest scientific activity in this field, with Research in Developmental Disabilities being the most prominent and the Cochrane Library database concentrating the largest number of articles. In addition, research has been conducted in Anglo-Saxon countries such as Canada and the United States, with an inclination towards writing articles individually and focused on disabilities such as Down Syndrome and Autism Spectrum Disorder. Regarding the characteristics of these interventions, it can be summarized that their format is group with a duration of approximately 2 hours per session, with the cognitive-behavioral approach and the behavioral control techniques being the most outstanding. Finally, the variable that has been more worked on is effective communication and the most widely used statistical test to measure the effects of interventions is MANOVA.
\end{abstract}

\section{Keywords:}

Children with disabilities, parents, intervention, randomized controlled trial

\section{Resumen:}

Los niños que nacen con una discapacidad específica, precisan de cuidadores primarios capacitados en atender y potencializar sus habilidades. El presente estudio es un análisis bibliométrico de las publicaciones de intervenciones psicológicas con ensayo controlado aleatorio (ECA) que se han realizado en padres de niños con discapacidad en el periodo de 1980 a 2019. Como parte de la estrategia de búsqueda, se hizo uso de las bases de datos Cochrane Library, Pubmed y Elsevier, realizando diferentes combinaciones con las palabras clave "niños con discapacidad", "padres", "intervención" y "ensayo controlado aleatorio". Los resultados obtenidos reflejan que el 2015 fue el año con mayor actividad científica en este campo, siendo la revista Research in Developmental Disabilities la que más destaca y la base de datos Cochrane Library la que concentra el mayor número de artículos. Además, las investigaciones se han realizado en países anglosajones como Canadá y Estados Unidos, con una inclinación hacia la elaboración de artículos de manera individual y centrados en discapacidades como el Síndrome de Down y el el trastorno del espectro autista. En cuanto a las características de estas intervenciones, se puede resumir que su formato es grupal con una duración aproximada de 2 horas por sesión, siendo el enfoque cognitivo-conductual y las técnicas de control conductual las que más destacan. Finalmente, la variable que más se ha trabajado es la comunicación efectiva y la prueba estadística más utilizada para medir los efectos de las intervenciones es el MANOVA.

\section{Palabras Clave:}

Niños con discapacidad, padres, intervención, ensayo controlado aleatorizado

\footnotetext{
Corresponding author, Universidad Autónoma del Estado de Hidalgo, https://orcid.org/0000-0003-2440-8126, Email: salinaskarla93@gmail.com

b Universidad Autónoma del Estado de Hidalgo, https://orcid.org/0000-0003-2440-8126, Email: salinaskarla93@gmail.com

${ }^{\mathrm{c}}$ Universidad Autónoma de Tamaulipas, https://orcid.org/0000-0003-1073-5855, Email: adyluz21@gmail.com
} 


\section{INTRODUCTION}

Disability as an object of study initially focused on knowing its causes and types, in addition to the peculiarities of each condition. From the psychological perspective, the experience of each subject as well as the factors aimed at achieving autonomy, the capacity for self-determination, incorporation into the workforce or, externally, the organization of resources and social services for integration and inclusion, defined for decades the direction to follow in this field of study (Espino \& Martín, 2014). Following the observations of this line of research, the influence of social support began to be glimpsed, specifically the role of the family nucleus in determining the capacity of psychoemotional, cognitive, and developmental skills, as well as the social and personal development of individuals, regardless of the condition, type or severity of the disability and the effect of any protective or risk factors present (Sánchez-Teruel \& Robles-Bello, 2015); It is then when a growing interest emerges to study the behavior of families living with disabilities in some of its members (Salazar-Farfán, 2017; Soriano \& Pons, 2013). Since the family is the entity that provides the care and support of each person, it fulfills vital functions such as satisfying basic survival needs during the first years of life. Parents, or primary caregivers, in addition to providing the context of the organization and initial development of cognitive, affective, motivational and volitional processes, they also build the values, qualities and character traits of each individual during childhood, as well as adolescence, which ultimately determine their capacities for adulthood (Espino \& Martín, 2014; MartínCala \& Tamayo-Megret, 2013).

It follows that various authors focused their study analysis on knowing the psycho-emotional phenomena associated with the parents of children with disabilities, (Salazar-Farfán, 2017; Morales, 2016; De María, 2015) the presence of initial grief, stress, anxiety, depression, isolation, shame, anger and guilt, these, in turn, impact the caregiver's initial bond with the disabled child (Duman, Gokten, Duman, Duman, \& Cevik, 2018; Fathizadeh, Takfallah, Badrali, Shiran, Savabi, \& Akhavan, 2012; Soriano \& Calatayud, 2013; Seguí, Ortiz, \& De Diego, 2008). The presence of these factors modifies the parenting style, many times with a tendency to overprotection, making it more difficult to promote the independence of the minor (Morales, 2016). The well-being of the family and, especially, the quality of life of the infant, will largely depend on the type of coping and psychosocial tools of the caregivers to stimulate the abilities of the infant despite the specific limitations of each disability (Espino \& Martín, 2014; Soriano \& Pons, 2013; De María, 2015). Although it has been observed that each caregiver responds differently to the situation of having a child with a disability, levels of parental stress are always more significant than those reported in parents of children without any abnormal condition (De María, 2015; Seguí, Ortiz, \& De Diego, 2008). It has been observed that parents who are less receptive to the emotional needs of their children, as well as those who tend to use avoidant coping behaviors and focus only on the emotional discharge, report higher levels of depression, anxiety and overload, coupled with a lower quality of life (Seguí, Ortiz, \& De Diego, 2008; Suriá, 2014), that in turn, negatively impact on the cognitive and psychosocial abilities of their children (Bei, 2015; Suriá, 2014).

On the other hand, studies focused on the analysis of resilient factors report a greater degree of adaptability and independence in children whose parents have greater social skills, problem-focused coping behaviors, predominance of democratic parenting style, existence of flexible thinking about parenting and about the disability of their child, perception of stable social support networks, high selfefficacy, better stress management, among other such factors. Their children usually report a better development of cognitive, psycho-emotional and social skills, despite the type of disability they have (De María, 2015; Bei, 2015; Mahoney \& Perales, 2012).

Thanks to the contributions of these studies, the importance of developing interventions, dedicated to adaptation skills and social, affective, and behavioral development of children with disabilities through the training of primary caregivers, becomes evident (Salazar-Farfán, 2017; Morales, 2016; De María, 2015; Seguí, Ortiz, \& De Diego, 2008). However, despite their relevance, research papers dedicated to determining the effectiveness of interventions for this phenomenon are still limited. This may be due to the relatively low prevalence of certain conditions of childhood disability, compared to the number of cases reported in adults (World Health Organization, 2011), without forgetting that these are populations with very specific characteristics, which make them less accessible, plus the complexity of the disability and its comorbidities further limit our capacity to study the patients.

Despite these conditions, evidence-based practice (EBP) is a resource that allows researchers to develop effective interventions based on the scientific method. EBP, being a methodological model, has a series of procedures that allow legitimizing treatments and techniques that report sufficient empirical evidence of good quality to support its results and can combine the professional's clinical practice (clinical judgment) with the best evidence obtained from a systematic research (Morán, 2011). Within the experimental research designs that follow EBP guidelines, randomized controlled trials (RCT) use a parallel design study with two groups, consisting of the selection of a sample of patients and their random assignment to one of the two groups. One of them receives the study intervention and the other the control intervention used as a reference or comparison. Both groups are followed concurrently during a given period, quantifying and comparing the responses observed in both (Ledesma \& Gutiérrez, 2013) (see Figure 1). 


\section{METHOD}

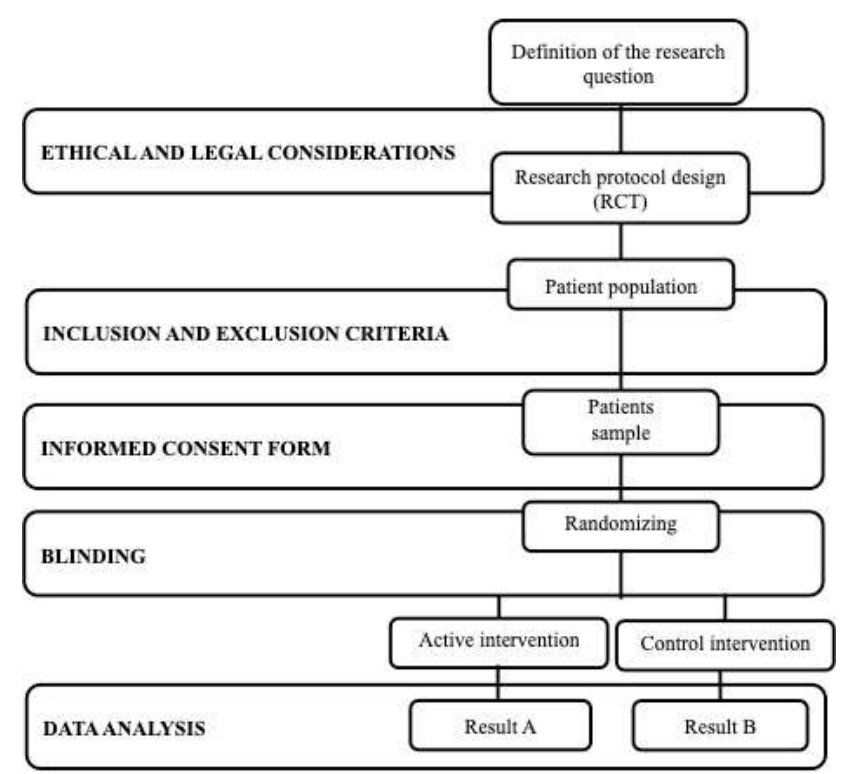

Figure 1.Design of a randomized controlled trial (RCT).

Own elaboration.

This type of design allows a planned experiment to be carried out in which, prospectively, two or more preventive, curative or rehabilitative interventions are compared, patients are assigned individually and randomly to a specific group, in order to study the efficacy and/or safety of said interventions in the population to be studied. Subject selection, treatment and follow-up periods take place simultaneously in all groups (intervention groups and control group) (Ledesma \& Gutiérrez, 2013).

This analysis promotes the collection, interpretation and integration of the evidence reported through the parameters of EBP in interventions with an RCT design, in order to support the development of an effective psychological professional practice for parents of children with disabilities, therefore serving as a theoretical support for future research dedicated to interventions in this population.
Design

The objective of this article was to carry out a comparative analysis of scientific papers published from 1980 to 2019, of intervention programs designed for parents of children with disabilities (motor, sensory, developmental and cognitive) with an experimental design of a randomized clinical trial (RCT).

Analysis Unit

For the development of this research, 9 scientific articles with RCT on intervention programs designed for parents of children with disabilities that were published between 1980 and 2019 in countries belonging to Europe, North America, Asia, and Oceania were analyzed ((Baker \& Brightman, 1984; Bearss et al., 2015; Girolametto, 1988; Hirvikoski, 2019; Kim \& Mahoney, 2005; Overbeek, Sterkenburg, Kef, \& Schuengel, 2015; Pelchat, Bisson, Ricard, Perreault, \& Bouchard, 1989; Sofronoff, Jahnel, \& Sanders, 2011; Stuttard, Beresford, Clarke, Beecham, Todd, \& Bromley, 2014).

Procedure

The articles were searched in the following databases: Cochrane Review Library, Research Gate, Elsevier, Pub Med, PsyNet and Medline using the keywords "children with disabilities", "parents", "intervention" and "randomized controlled trial". The studies were coded using the following parameters: 1) year of publication, 2) number of authors, 3) database, 4) RCT design, 5) country of origin, 6) type of disability of the minors, 7) number of subjects, 8) duration of intervention, 9) frequency of intervention, 10) components, 11) main results, 12) follow-up time, 13) pre-treatment evaluation, 14) post-treatment evaluation, 15) instruments used. In the second phase, the information from each of the articles was collected in the database. Finally, in the third phase, the information analysis was carried out considering the variables that had been collected.

\section{RESULTS}

We found 9 articles meeting the inclusion criteria and summarized them in the following descriptive tables. Table 1 shows a first publication in 1984, and two more in 1988 and 1999 , followed by a 16-year hiatus until an isolated study in 2005 , then a shorter 6-year hiatus followed by 5 more evenly spaced studies, two of them in 2015 and the last published in 2019. 
Table 1

Published articles by year of publication.

\begin{tabular}{ccc}
\hline $\mathbf{z}$ & Frecuency & Percentage (\%) \\
\hline 1984 & 1 & 11.1 \\
1988 & 1 & 11.1 \\
1989 & 1 & 11.1 \\
2005 & 1 & 11.1 \\
2011 & 1 & 11.1 \\
2014 & 1 & 11.1 \\
2015 & 2 & 22.2 \\
2019 & 1 & 11.1 \\
\hline
\end{tabular}

Table 2 shows the number of authors in each article. There were 3 articles with one author, 2 with two authors, and one each with 3, 4, 6 and 23 authors. The mean number of primary caregivers participating in all studies was 62.7 patients, ranging from 9 to 180 . We observed a firm tendency for greater number of subjects with a higher number of authors.

Table 2

Number of authors per article

\begin{tabular}{ccc}
\hline Number of authors & n of articles & $\begin{array}{c}\text { Percentage } \\
(\%)\end{array}$ \\
\hline 1 & 3 & 33.3 \\
2 & 2 & 22.2 \\
3 & 1 & 11.1 \\
4 & 1 & 11.1 \\
6 & 1 & 11.1 \\
23 & 1 & 11.1 \\
\hline
\end{tabular}

Table 3

Included journals

\begin{tabular}{lcc}
\hline \multicolumn{1}{c}{ Journal } & SJR score/Country & $\begin{array}{c}\text { n of } \\
\text { articles. }\end{array}$ \\
\hline $\begin{array}{l}\text { International Journal } \\
\text { of Nursing Studies }\end{array}$ & $\begin{array}{c}1.56, \mathrm{Q} 1 \\
\text { United Kingdom }\end{array}$ & 1 \\
$\begin{array}{l}\text { Journal of the } \\
\text { American Medical }\end{array}$ & $\begin{array}{c}7.48, \mathrm{Q} 1 \\
\text { Unsociation }\end{array}$ & 1 \\
$\begin{array}{l}\text { Journal of Behavior } \\
\text { Therapy and }\end{array}$ & $\begin{array}{l}1.38, \mathrm{Q} 1 \\
\text { Experimental } \\
\text { Psychiatry }\end{array}$ & 1 \\
$\begin{array}{l}\text { Journal of Speech, } \\
\text { Language, and } \\
\text { Hearing Research }\end{array}$ & United Kingdom & \\
$\begin{array}{l}\text { ClinicalTrials.gov } \\
\text { United }\end{array}$ & 1 \\
Trials & United States & 1 \\
$\begin{array}{l}\text { Research in } \\
\text { Developmental } \\
\text { Disabilities }\end{array}$ & $1.29, \mathrm{Q} 1$ & 1 \\
\hline
\end{tabular}

According to the results in Table 4, the Cochrane Library has the highest percentage $(44.4 \%)$ of publications with interventions for parents of children with disabilities collected in their database.

Table 3 shows that the journal Research in Developmental Disabilities, published three of the nine articles. One of the articles and its results, was accessed in the webpage ClinicalTrials.gov, which is a resource of the National Library of Medicine (NLM). On the other hand, all the journals we analyzed have the Scimago Journal Rank (SJR) indicator, an impact factor that is supported by the information provided by the Scopus database (Elsevier), and which considers the prestige and thematic area of a journal to calculate the determined value of the citations it has: the higher the SJR score, the higher the publication's value. Furthermore, all the journals included in the analysis are in quartile Q1, indicative of journals located in an important position as compared to other journals in the same area. The journal's most frequent country of origin was the United Kingdom, followed by the United States. 
Table 4

Articles per database

\begin{tabular}{ccc}
\hline Database & n of articles & Percentage (\%) \\
\hline Cochrane Library & 4 & 44.4 \\
Elsevier & 2 & 22.2 \\
Pubmed & 3 & 33.3 \\
\hline
\end{tabular}

Table 5 shows that North America (not including Mexico), has the largest percentage of RCTs for caregivers of children with disabilities, followed by Europe (33.3\%) and one each from South Korea and Australia.

Table 5

Articles per country

\begin{tabular}{lcc}
\hline \multicolumn{1}{c}{ Country } & Frequency & Percentage(\%) \\
\hline Netherlands & 1 & 11.1 \\
Australia & 1 & 11.1 \\
Canada & 2 & 22.2 \\
South Korea & 1 & 11.1 \\
United States & 2 & 22.2 \\
United Kingdom & 1 & 11.1 \\
Sweden & 1 & 11.1 \\
\hline
\end{tabular}

Table 6 summarizes the frequency of disabilities studied. Down's syndrome and Autistic Spectrum Disorder (ASD) are reported in 4 articles each, followed by blindness, intellectual disability and cerebral palsy in 3 articles each. Visual weakness is included in only one article.

Table 6

Articles per disability.

\begin{tabular}{lc}
\multicolumn{1}{c}{ Type of disability } & n of articles \\
\hline Blindness & 3 \\
Visual weakness & 1 \\
Intellectual disability & 3 \\
Cerebral palsy & 3 \\
Down's Syndrome & 4 \\
ASD & 4 \\
\hline
\end{tabular}

Note: ASD=Autistic spectrum disorder

Most studies used group interventions of caregivers (66.6\%), two used individual interventions, and one reported mixed sessions (Table 7). It is worth mentioning that the average number of sessions recorded in the analysis is 8, with a minimum of 2 sessions and a maximum of 13 .

Table 7

Articles per type of intervention

\begin{tabular}{lcc}
\hline Intervention format & Frequency & Percentage (\%) \\
\hline Individual & 2 & 22.2 \\
Group & 6 & 66.6 \\
Mixed & 1 & 11.1 \\
\hline
\end{tabular}

As observed in Table 8, the most frequent duration reported for each session is two hours, with a prevalence of $66.6 \%$ of the studies, followed by one and a half hours (22.2\%). Only one study $(11.1 \%)$ reported sessions lasting three and a half hours.

Table 8

Articles per duration of sessions

\begin{tabular}{ccc}
\hline Duration in hours & Frequency & Percentage $(\%)$ \\
\hline 1.5 & 2 & 22.2 \\
2 & 6 & 66.6 \\
3.5 & 1 & 11.1 \\
\hline
\end{tabular}

The most frequent type of theoretical approach of the intervention used was Cognitive-behavioral in $77.7 \%$ of the studies (Table 9).

Table 9

Articles per theoretical approach of the interventions.

\begin{tabular}{lcc}
\hline $\begin{array}{c}\text { Theoretical } \\
\text { approach of the } \\
\text { interventions }\end{array}$ & Frequency & Percentage (\%) \\
\hline Not specified & 1 & 11.1 \\
$\begin{array}{l}\text { Psychoeducational } \\
\begin{array}{l}\text { Cognitive-behavioral } \\
\text { therapy }\end{array}\end{array}$ & 1 & 11.1 \\
\hline
\end{tabular}

Table 10 shows that the variable that has been studied the most in parents of children with disabilities is affective communication ( 5 articles report it), followed by parental stress (3 articles), and disruptive behaviors of the child (3 articles). It is worth mentioning that despite the fact that this 
last variable is intrinsic to minors, it is worked on indirectly through parents training. Other components that have been worked on are emotional distress, anxiety, marital support, self-efficacy, language behaviors of the child, depression, parenting styles, father-mother-child interaction, and sensibility, as shown in Table 10.

Table 10

Articles per worked variable

\begin{tabular}{lc}
\multicolumn{1}{c}{ Worked variable } & n of articles \\
\hline Emotional distress & 1 \\
Anxiety & 1 \\
Marital support & 1 \\
Self-efficacy & 1 \\
$\begin{array}{l}\text { Language behaviors of the } \\
\text { child }\end{array}$ & 1 \\
$\begin{array}{l}\text { Disruptive behaviors of the } \\
\text { child }\end{array}$ & 4 \\
Effective communication & 5 \\
Depression & 1 \\
Parenting styles & 1 \\
Parental stress & 4 \\
$\begin{array}{l}\text { Father/mother-child } \\
\text { interaction } \\
\text { Sensibility }\end{array}$ & 3 \\
\hline
\end{tabular}

Table 11 shows that the preferred intervention in this population are behavioral control techniques (reported in 5 articles), followed by play therapy and psychoeducation (4 articles each). Other reported techniques are mindfulness, skills training, modeling and problem solving.
Table 11

Articles per intervention technique

\begin{tabular}{lc}
\multicolumn{1}{c}{ Technique } & n of articles \\
\hline Mindfulness & 1 \\
Skill training & 2 \\
Play therapy & 4 \\
Modeling & 2 \\
Psychoeducation & 4 \\
Behavioral control techniques & 5 \\
Problem solving & 2 \\
\hline
\end{tabular}

Finally, Table 12 shows that the statistical test most frequently used in this type of intervention is the Multivariate Analysis of Variance (MANOVA), since four articles report its use. They are followed by the Analysis of Covariance (ANCOVA), Analysis of Variance (ANOVA) and random regression model.

Table 12

Articles per type of statistical analysis

\begin{tabular}{lc}
\multicolumn{1}{c}{ Statistical test used } & N of articles \\
\hline ANCOVA & 2 \\
ANOVA & 2 \\
MANOVA & 4 \\
Random regression analysis & 1 \\
\hline
\end{tabular}




\section{DISCUSSION}

The eighties saw the first scientific publications using an RCT design for studying interventions on parents of children with disabilities, the article by Girolametto (1984) being the first. Subsequently, there was an absence of scientific activity in the 1990s and early 2000s, until in 2005 a single article developed in South Korea by Kim and Mahoney was published. Again, a period of absence of publications happened until 2011. From this moment on, greater constancy in the production of articles is observed, being 2015 the year that stands out the most in terms of the number of articles reported.

Regarding the number of authors who collaborate in the writing of an article, most had either one or two authors, and only one article reported 23 researchers, highlighting that proportionally the sample size increased considerably compared to the other studies. The advantages of being able to capture a larger number of participants in such specific populations are reflected, through the participation of various researchers.

On the other hand, the journals that publish most of the aforementioned articles use English language and are mostly published in the United Kingdom (International Journal of Nursing Studies, Journal of Behavior Therapy and Experimental Psychiatry, Trials, Research in Developmental Disabilities) and in the United States (Journal of the American Medical Association and Journal of Speech, Language, and Hearing Research). The journal Research in Developmental Disabilities stands out with the publication of 3 of the articles. Likewise, we found that all magazines have the SJR indicator in the Q1 quartile, indicative of journals located in an important position compared to other journals in the same area. This is relevant, as it supports the data obtained through a more rigorous and scientific methodology, resulting in evidence-based research.

Regarding database, the largest number of articles was obtained, from the Cochrane Library, with 4 reported publications, followed by Pubmed with 3 and Elsevier with 2 articles. The first database specializes in the compilation of studies by means of systematic reviews and meta-analysis of different study phenomena, as well as the compilation of publications from various scientific journals, which increases the probability of finding a greater number of quality publications.

The countries with the highest percentage of scientific publications in our area of interest were the United States and Canada, followed by countries from Europe, Asia and Oceania. Despite the high prevalence of childhood disability worldwide (World Health Organization, 2011), no RCT studies in caregivers of children with disabilities were reported from Spanish-speaking countries. In addition to this, it is important to consider the differences in the social and health context that many Latin American countries experience, which may be influencing the advance or decline of research in this and other fields.

The articles analyzed report a higher frequency of children with developmental disabilities (e.g. Down's Syndrome and ASD), followed by sensory disabilities, in particular visual disability (reported in 3 articles). For other conditions such as deafness, the treatment of primary caregivers using RCT design was not reported in any of the included studies. It is worth mentioning that the comorbidity of some disabilities with the presence of disorders or other conditions can make it difficult to define the study population and the structure of the intervention design.

Regarding the format of the interventions of the analyzed studies, the majority reported working with caregivers in a group modality. Two articles used individually applied treatments and only one study reported addressing the sessions in a mixed way. This may be due to the fact that working with groups saves financial resources and time, in addition to making it possible to cover a greater number of participants, who can be provided with social support as part of the dynamics that this modality implies. In addition to this, it is worth mentioning that the highest prevalence, in terms of the time of each session, was two hours, reported in six of the nine studies analyzed although it is a similar time as the two studies that reported sessions of one and a half hours. Only one study reported a very different approach, with sessions lasting three and a half hours.

Regardless of the time and presentation of the treatment, the theoretical basis is the most important intervention feature regarding results. The Cognitive Behavioral approach is part of the design of most of the studies (reported in seven out of nine). Its effectiveness is supported by a solid empirical base. This model has managed to efficiently improve interventions in clinical practice, with scientific evidence in diverse populations with both general and specific characteristics. Therefore, its use is consistent to define the treatment method and increase the probability of effectively training caregivers of children with disabilities.

The authors of each study mostly opted to intervene through this approach, the variables to be modified differ according to their relevance to the authors and the type of disability of the minors. Components such as emotional distress, anxiety, marital support, self-efficacy, language behaviors of the child, depression, parenting styles, father/mother-child interaction and sensibility were reported in the analyzed studies. Likewise, affective communication stands out among the predominant variables addressed, since it was measured in 5 articles, followed by parental stress reported in 3 articles. Another reported variable, is the decrease in disruptive behaviors of the child, reported in 3 articles. It is worth mentioning that despite the fact that this last variable is intrinsic to minors, as mentioned by authors such as Mahoney and Perales (2012), work is done indirectly on them through the training of caregivers. 
As part of the analysis of this study, we also investigated the intervention techniques reported in the articles. Some techniques that are reported are: mindfulness, skill training, modeling and problem solving. However, there is a predominance in the use of strategies of behavioral control that aim to modulate the behavior of minors, reported in 5 articles. They are followed by play therapy and psychoeducation Finally, despite the possible limitations of generating studies with representative samples in this type of context, it does not detract from the possible findings that can be obtained as a result of these investigations. Reported in 4 articles each.

A substantial piece of information that allows us to determine the effectiveness of an intervention program lies in the choice of statistical test to treat the data of the variables measured in these studies. According to the analysis of the collected research, the Multivariate Analysis of Variance (MANOVA), mentioned in four articles, was used more frequently; followed by Analysis of Covariance (ANCOVA), then Analysis of Variance (ANOVA) and a random regression model.

It is worth mentioning that the results obtained in the comparison of before and after, these studies report positive changes, although in some of them a statistically significant difference in the decrease or increase in the scores of some of the variables studied was not reached.

Despite the evidence supported by research, it is risky to give conclusive opinions about the extent of the effect of the interventions on the lives of children or caregivers. Despite this, the need to continue implementing this type of study is notable, in particular in contexts such as those of Latin American countries, where the sociodemographic and cultural conditions do not resemble those reported in these studies.

To achieve this goal, it is important to continue generating scientific studies, specially RCTs, that measure and report the investigations belonging to this line of study.

\section{CONCLUSIONS}

Bibliometric studies allow us to observe the interest of journals of scientific dissemination, as well as the production of researchers on topics they consider relevant. It also allows us to make a critical analysis of the current situation of an area of knowledge to understand the details that the studies address. and those which are being left out without enough attention.

According to the research carried out so far, we observe a need to expand the state of the art on the phenomenon experienced by families of people with disabilities, particularly of their primary caregivers.

One of the factors to consider is the social and cultural context where these families develop. Despite having studies done in Europe and the United States, it remains important to know the behavior of the reported variables in regions with a different culture and different health systems, such as Latin America. The scientific production of reports with this line of research becomes substantial for improving the state of the art in the study of disability and its psychosocial implications. In particular, the implementation of intervention programs for this type of population through evidence-based clinical practice and the use of experimental research designs, allows for greater empirical support of the results in order to generate effective action paths that provide the best care. and development for these vulnerable populations.

Simultaneously, the publication and dissemination of this type of work contributes to raising awareness of the underserved needs of this vulnerable population.

Finally, despite the possible limitations of generating studies with representative samples in this type of context, it does not detract from the possible findings that can be obtained as a result of these investigations.

\section{REFERENCES}

Baker, B., \& Brightman, R. (1984). Training parents of retarded children: program-specific outcomes. Journal of Behavior Therapy and Experimental Psychiatry, 15(3), 255-260. doi: https://doi.org/10.1016/00057916(84)90034-X

Bearss, K., Johnson, C., Smith, T., Lecavalier, L., Swiezy, N., Aman, M., ... Scahill, L. (2015). Effect of parent training vs parent education on behavioral problems in children with autism spectrum disorder: a randomized clinical trial. Journal of the American Medical Association, 313(15), 1524-1533. doi: https://doi.org/10.1001/jama.2015.3150

Bei, E. (2015). Efectos de la estimulación y el vínculo afectivo en el desarrollo sensorio-motor y cognitivo de los bebés no videntes [Tesis de Doctorado en Psicología] Universidad Católica Argentina. Facultad de Psicología y Psicopedagogía.

De María, P. (2015). Afrontamiento y Estilos de Crianza en Padres de niños con discapacidad. Recuperado de https://bit.ly/3dpm3Lf

Duman, N., Gokten, E., Duman, R., Duman, R., \& Cevik, S. (2018). Evaluation of Depression and Anxiety Levels in Mothers of Babies' Following Due to Premature Retinopathy. Archives of Psychiatric Nursing, 32(3), 439443. doi: https://doi.org/10.1016/j.apnu.2017.12.011

Espino, J., \& Martín, A. (2014). Estudio de factores resilientes en familiares de personas con discapacidad. Revista INFAD de Psicología. International Journal of Developmental and Educational Psychology, 7(1), 407416. doi: https://d oi.org/10.17060/ijodaep.2014.n1.v7.810

Fathizadeh, N., Takfallah, L., Badrali, N., Shiran, E., Savabi, M., \& Akhavan, H. (2012). Experiences of blind children caregivers. Iranian Journal of Nursing and Midwifery Research, 17(2), 143-149. Recuperado de 
https://www.researchgate.net/publication/247158094_Expe riences_of_blind_children_caregivers

Girolametto, L. (1988). Improving the social-conversational skills of developmentally delayed children. Journal of Speech, Language, and Hearing Research, 53(2), 156167. doi: https://doi.org/10.1044/jshd.5302.156

Hirvikoski, T. (2019). ClinicalTrials.gov. ACT -Groups for Parents to Children With Disabilities (Navigator ACT). Recuperado https://clinicaltrials.gov/ct2/show/NCT03830476

Kim, J. \& Mahoney, G. (2005). The effects of relationship focused intervention on Korean parents and their young children with disabilities. Research in Developmental Disabilities, 26(2): 117-30. doi: https://doi.org/10.1016/j.ridd.2004.08.001

Ledesma, J. M., \& Gutiérrez, M. (2013). Más allá de la clínica. Estudios experimentales. Ensayo clínico aleatorizado. Formación Activa en Pediatría de Atención Primaria, 6(2), 123-132. Recuperado de http://archivos.fapap.es/files/639-945-

RUTA/19_FAPAP2_2013_06_OK.pdf

Mahoney, G., \& Perales, F. (2012). El papel de los padres de niños con síndrome de Down y otras discapacidades en la atención temprana. Revista Síndrome de Down, 29, 46-64. Recuperado de https://www.researchgate.net/publication/277264411_El_p apel_de_los_padres_de_ninos_con_sindrome_de_Down_y _otras_discapacidades_en_la_atencion_temprana

Martín-Cala, M., \& Tamayo-Megret, M. (2013). Funciones básicas de la familia. Reflexiones para la orientación psicológica educativa. EduSol, 13(44), 60-71. Recuperado de https://www.redalyc.org/pdf/4757/475748683007.pdf

Morales, L. C. (2016). Experiencias de padres de niños ciegos: un camino con grandes desafíos. Revista de la Universidad Industrial de Santander. Salud, 48(3), 331340. doi: http://dx.doi.org/10.18273/revsal.v48n32016007

Morán, L. (2011). La práctica basada en evidencia, algunos desafíos para su integración en el currículum del pregrado de enfermería. Enfermería Universitaria, 8(4), 4-7. Recuperado de http://www.scielo.org.mx/pdf/eu/v8n4/v8n4a1.pdf

Organización Mundial de la Salud. (2011). Resumen Informe Mundial sobre la Discapacidad. Recuperado de https://www.who.int/disabilities/world_report/2011/summ ary_es.pdf?ua=1

Overbeek, M. M., Sterkenburg, P. S., Kef, S., \& Schuengel, C. (2015). The effectiveness of VIPP-V parenting training for parents of young children with a visual or visual-andintellectual disability: study protocol of a multicenter randomized controlled trial. Trials, 16(1), 2-11. doi: https://doi.org/10.1186/s13063-015-0916-6

Pelchat, D., Bisson, J., Ricard, N., Perreault, M., \& Bouchard, J. (1989). Longitudinal effects of an early family intervention programme on the adaptation of parents of children with a disability. International Journal of Nursing Studies, 36(6), 465-477. doi: https://doi.org/10.1016/S0020-7489(99)00047-4

Salazar-Farfán, M. (2017). Padres de niños con discapacidad. Relación y diferencias entre inteligencia emocional y resiliencia. CASUS. Revista de Investigación y Casos en Salud, 2(3), 156-162. doi: https://doi.org/10.35626/casus.3.2017.50

Sánchez-Teruel, D., \& Robles-Bello, M. A. (2015). Respuesta a un programa de resiliencia aplicado a padres de niños con Síndrome de Down. Universitas Psychologica, 14(2), 645-657. doi: https://doi.org/10.11144/Javeriana.upsy141.rpra

Seguí, J. D., Ortiz-Tallo, M., \& De Diego, Y. (2008). Factores asociados al estrés del cuidador primario de niños con autismo: sobrecarga, psicopatología y estado de salud. Anales de Psicología, 24(1), 100-105. Recuperado de https://digitum.um.es/digitum/bitstream/10201/8145/1/Fact ores $\% 20$ asociados $\% 20$ al $\% 20$ estres $\% 20 \mathrm{del} \% 20$ cuidador $\% 2$ 0primario $\% 20 \mathrm{de} \% 20$ ninos $\% 20$ con\%20autismo.pdf

Sofronoff, K., Jahnel, D., \& Sanders, M. (2011). Stepping Stones Triple $\mathrm{P}$ seminars for parents of a child with a disability: a randomized controlled trial. Research in Developmental Disabilities, 32(6), 2253-2262. doi: https://doi.org/10.1016/j.ridd.2011.07.046

Soriano, M. E., \& Pons, N. (2013). Recursos percibidos y estado emocional en padres de hijos con discapacidad. Revista de Psicología de la Salud, 1(1), 84-101. doi: https://doi.org/10.21134/pssa.v1i1.375

Stuttard, L., Beresford, B., Clarke, S., Beecham, J., Todd, S., \& Bromley, J. (2014). Riding the Rapids: Living with autism or disability - An evaluation of a parenting support intervention for parents of disabled children. Research in Developmental Disabilities, 35(10), 2371-2383. doi: https://doi.org/10.1016/j.ridd.2014.05.021

Suriá, R. (2013). Análisis comparativo de la fortaleza en padres de hijos con discapacidad en función de la tipología y la etapa en la que se adquiere la discapacidad. Anuario de Psicología/The UB Journal of Psychology, 43(1), 23- 
37.

Recuperado

de

https://www.redalyc.org/articulo.oa?id=97027472002

Suriá, R. (2014). Análisis del empoderamiento en padres y madres de hijos con discapacidad. Boletín de Psicología,
(110),
83-97.
Recuperado
de

https://www.uv.es/seoane/boletin/previos/N110-6.pdf 